\title{
Keterbukaan Informasi Publik Untuk Mendukung Kinerja Aparatur Sipil Negara Yang Berkarakter Dan Proporsional
}

\author{
“Laurensius Arliman $S^{l ”}$
}

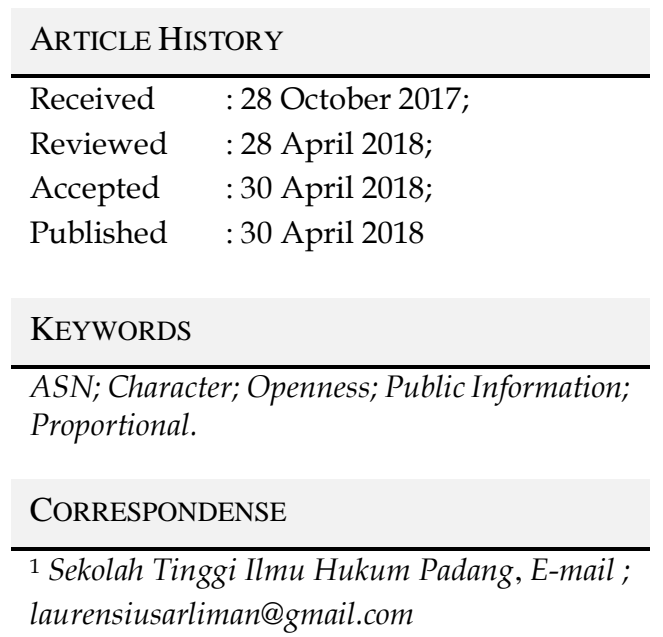

\section{Pendahuluan}

Indonesia sebagai Negara Hukum Demokrasi, sebagaimana ditegaskan dalam Pasal 1 ayat (2) dan ayat (3) Undang-Undang Dasar Negara Republik Indonesia Tahun 1945 (UUD 45), sudah barang tentu pemerintahnya bertanggungjawab dalam hal penyelenggaraan negara atau pemerintahaannya kepada rakyat. Salah satu bentuk tanggungjawab pemerintah disini adalah dengan adanya keterbukaan informasi publik. Selanjutnya, Pasal 28 F UUD

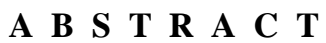

State civil service (ASN) resource management is an important part of state governance that aims to assist and support all human resources of state civil apparatus to realize their full potential as civil servants and citizens. One is the openness of public information described in the UU ASN and the Law on Public Information Disclosure (UU KIP). The implications of the application of the KIP Law to the public or the public are the opening of access for the public to obtain information related to the public interest. First, Information that must be provided and announced and Required Information Announced necessarily (easy to reach and easy to understand). Establishing characterized and proportional ASNs are various ways, namely: 1) State Civil Service Committee (KASN); 2) Utilizing information communication technology (ICT), which provides public information disclosure data to the public through the website; 3) Implementation of UU KIP; 4) need to be socialized both to public bodies and communities; 5) Public bodies are given space to establish, build, and develop institutional PPIDs in accordance with the characteristics of institutions of their respective public bodies; 6) The government should be able to optimize socialization and encourage public participation to be able to carry out information disclosure, as mandated by UU KIP. With these means are expected to realize the character of ASN and proportional that also amandat of UU KIP.
\end{abstract}

45 menyatakan bahwa: Setiap orang berhak untuk berkomunikasi dan memperoleh informasi untuk mengembangkan pribadi dan lingkungan sosialnya, serta berhak untuk mencari, memperoleh, memiliki, menyimpan, mengolah, dan menyampaikan informasi dengan menggunakan segala jenis saluran yang tersedia. Dengan adanya transparansi atas informasi publik tentang kinerja pemerintah dalam melaksanakan penyelenggaraan negara atau pemerintahaannya, membuat masyarakat dapat ikut berpartisipasi aktif mengontrol 
setiap langkah dan kebijakan yang diambil pemerintah. ${ }^{1}$ Sehingga penyelenggaraan pemerintahan dapat dipertanggungjawabkan kepada rakyat.

Atas hal tersebut manajemen sumber daya aparatur sipil negara merupakan salah satu bagian penting dari pengelolaan pemerintahan negara yang bertujuan untuk membantu dan mendukung seluruh sumber daya manusia aparatur sipil negara untuk merealisasikan seluruh potensi mereka sebagai pegawai pemerintah dan sebagai warga negara. Paradigma ini mengharuskan perubahan pengelolaan sumber daya tersebut dari perspektif lama manajemen kepegawaian yang menekankan hak dan kewajiban individual pegawai menuju pespektif baru yang menekankan pada manajemen pengembangan sumber daya manusia secara strategis (strategic human resource management) agar selalu tersedia sumber daya aparatur sipil negara unggulan selaras dengan dinamika perubahan misi aparatur sipil negara. Perubahan tersebut memerlukan manajemen pengembangan sumber daya manusia aparatur negara agar selalu maju dan memiliki kualifikasi dan kompetensi yang diperlukan untuk melaksanakan tugas dan fungsi pemerintahan dan pembangunan selaras dengan berbagai tantangan yang dihadapi bangsa Indonesia. ${ }^{2}$

Dalam rangka mencapai visi, misi dan tujuan pemerintahan yang telah ditetapkan bersama, diperlukan kondisi yang kondusif dan keharmonisan antar instansi pemerintah, pegawai yang satu dengan yang lain, yang masing-masing mempunyai peran yang cukup besar dalam mencapai tujuan pemerintahan. Pegawai merupakan salah satu tenaga pemerintahan yang mempunyai peran sebagai faktor penentu keberhasilan tujuan organisasi, karena pegawai langsung bersinggungan dengan masyarakat untuk memberikan pelayanan. Untuk itu kinerja para pegawai harus selalu ditingkatkan. Untuk mencapai

1 Endang Retnowati (2012). “Keterbukaan Informasi Publik Dan Good Governance (Antara Das Sein Dan Das Sollen)". Jurnal Perspektif. 17 (1): 55 .

2 Dewan Perwakilan Rakyat (2014). Naskah Akademik Rancangan Undang-Undang Tentang tujuan tersebut, dibutuhkan sumber daya manusia (pegawai) yang berkualitas. Disiplin pegawai sangat erat kaitannya terhadap kualitas atau kinerja organisasi yang secara konsisten harus selalu dijaga dan ditingkatkan.

Pasal 3 Undang-Undang Nomor 14 Tahun 2008 tentang Keterbukaan Informasi Publik (UU KIP), misalnya tercantum beberapa tujuan sebagai berikut: (1) Menjamin hak warga negara untuk mengetahui rencana pembuatan kebijakan publik, program kebijakan publik, dan proses pengambilan keputusan publik, serta alasan pengambilan suatu keputusan publik; (2) Mendorong partisipasi masyarakat dalam proses pengambilan kebijakan publik; (3) Meningkatkan peran aktif masyarakat dalam pengambilan kebijakan publik dan pengelolaan Badan Publik yang baik; (4) Mewujudkan penyelenggaraan negara yang baik, yaitu yang transparan, efektif dan efisien, akuntabel serta dapat dipertanggungjawabkan; (5) Mengetahui alasan kebijakan publik yang mempengaruhi hajat hidup orang banyak; (6) Mengembangkan ilmu pengetahuan dan mencerdaskan kehidupan bangsa; dan/atau (7) Meningkatkan pengelolaan dan pelayanan informasi di lingkungan Badan Publik untuk menghasilkan layanan informasi yang berkualitas. ${ }^{3}$ Regulasi tersebut menekankan pentingnya akses dan partisipasi masyarakat agar terwujud transparansi publik, terutama mencakup sumber-sumber informasi publik melalui proses partisipasi aktif dengan derajat kesadaran politik yang tinggi. Melalui jaminan akses dan partisipasi masyarakat itulah dimungkinkan kebijakan banyak dipengaruhi oleh nalar publik sehingga memiliki legitimasi kuat sebagaimana diisyaratkan skema demokratisasi pengambilan keputusan publik.

Pasca UU KIP diberlakukan, beberapa Badan Publik sedikit demi sedikit telah melakukan perubahan dalam hal pemberian informasi ke publik. Dari pengalaman para pelaksana kehumasan pemerintah, terlihat bahwa sejak

Aparatur Sipil Negara. Jakarta: Sekretariat Jenderal Dewan Perwakilan Rakyat, p. 1.

3 Pratikno, et-al. (2012). Kajian Implementasi Keterbukaan Informasi Dalam Pemerintahan Lokal Pasca Undang-Undang Nomor 14 Tahun 2008. Jakarta: Yayasan Tifa, p. 2. 
diberlakukannya UU KIP, telah banyak masyarakat yang mengetahui dan memanfaatkannya, baik perseorangan maupun bersama-sama dalam suatu kelembagaan, untuk mendapatkan informasi publik tentang kegiatan yang dilakukan oleh Badan Publik. Hal ini memang dijamin serta ditegaskan dalam Pasal 4 UU KIP yang menyatakan, bahwa setiap orang berhak memperoleh informasi publik sesuai dengan ketentuan undang-undang. Informasi dimohon secara tertulis maupun langsung. Keterbukaan informasi yang berkembang dan kebutuhan informasi publik yang meluas akan mendorong semakin banyak lagi masyarakat yang memanfaatkan haknya untuk meminta informasi publik yang ingin diketahuinya. Tentu saja hal ini tidak bisa dianggap remeh oleh Badan Publik, karena sesuai ketentuan, permohonan masyarakat wajib dilayani bahkan dalam waktu yang sudah ditetapkan yaitu 10 hari kerja sejak diterimanya permintaan (Pasal 22 ayat 7), meskipun dapat diperpanjang paling lambat 7 hari kerja (Pasal 22 ayat 8). Mengingat hal tersebut maka sebuah informasi perlu dikemas dan dikelola sedemikian rupa agar masyarakat mudah mengakses informasi yang mereka butuhkan. Ketika sebuah informasi dikemas dengan baik, maka akan dapat mendukung berkembangnya partisipasi publik dan hubungan yang ideal antara masyarakat dengan pemerintah. ${ }^{4}$

Dengan membuka akses publik terhadap informasi diharapkan badan publik termotivasi untuk bertanggungjawab dan berorientasi pada pelayanan rakyat yang sebaik- baiknya. Dengan demikian, hal ini dapat mempercepat perwujudan pemeintahan yang terbuka merupakan upaya strategis mencegah praktik Korupsi, Kolusi, Nepotisme (KKN), dan terciptanya kepemerintahan yang baik (Good Governance). Sesuai diterapkannya UU KIP, setiap lembaga pelayanan publik harus memberikan informasi dengan pengecualian hal-hal yang menyangkut keamanan Negara, hak pribadi, dan hal-hal yang diatur oleh undang-undang. Kebebasan informasi yang merupakan salah satu hak asasi manusia

4 C. Suprapti Dwi Takariani. (2014) "Pengelolaan Informasi Oleh Badan Publik Pemerintah Paska
(HAM) tidak akan efektif apabila masyarakat tidak diberi akses informasi yang lebih luas karena sesungguhnya keterbukaan informasi merupakan dasar bagi kehidupan demokrasi. Kebebasan informasi adalah perangkat masyarakat untuk mengontrol setiap langkah penyelenggaraan Negara. Dalam sebuah sistem demokrasi yang menyatakan kekuasaan peerintahan berasal dari rakyat sebagai kekuasaan, selayaknya rakyat juga memiliki hak mengkritis dan mengontrol setiap kebijakan yang diambil pemerintah.

Implementasi UU KIP tersebut sejak ditetapkan pada tahun 2008 lalu tentu perlu dipelajari dan dikaji, apakah berhasil mendorong inisiatif dan inovasi dalam mewujudkan penyelenggaraan tata pemerintahan yang baik ataukah belum. Paling tidak kita akan menemukan derajat keberhasilan, keterbatasan, peta masalah yang terjadi serta berbagai dinamika penyelenggaraan keterbukaan informasi untuk keperlukan pembenahan ke depan. Terkait Aparatur Sipil Negara (ASN) sebagai masalah sumber daya manusia sebagai penunjang terhadap keterbukaan informasi di pemerintahan, masalah yang terjadi adalah masih banyak masyarakat yang kesuliatan untuk mengakses informasi dari pemerintah. Meskipun saat ini sebagian masyarakat sudah sadar akan dampak pemberlakuan UndangUndang itu dapat membuka akses dalam mendapatkan informasi serta sebagai sarana mengawasi kebijakan publik, namun dalam pelaksanaannya belum banyak yang memanfaatkan secara optimal. Atas hal tersebut penulis melalui tulisan ini ingin melihat bagaimana keterbukaan informasi publik untuk mendukung kinerja ASN yang berkarakter dan proporsional, sehingga mewujudkan keterbukaan informasi yang lebih baik lagi.

Adapun rumusan masalah yang penulis ingin gali di dalam tulisan ini adalah: 1) bagaimana dampak UU KIP terhadap keterbukaan informasi di Indonesia? 2) bagamaimana membentuk kinerja ASN yang berkakter dan proporsional pasca berlakuknya UU KIP?

Reformasi Birokrasi". Jurnal Observasi, 12 (1), p. 29. 
Terkait hal tesebut tujuan dari penulisan ini sepadan dengan rumsuan masalah yang penulis sampaikan, yaitu untuk mengetahui dan menganalisis dampak UU KIP terhadap keterbukaan informasi di Indonesia, serta ingin mengetahui dan menganalisis kinerja ASN yang berkakter dan proporsional pasca berlakuknya UU KIP.

\section{Metode Penelitian}

Penelitian karya ilmiah ini, berjenis penelitian hukum normatif (yuridis normati)f, yaitu penelitian yang bertujuan untuk meneliti asasasas hukum, sistematika hukum, sinkronisasi hukum, sejarah hukum dan perbandingan hukum, ${ }^{5}$ penelitian ini difokuskan untuk mengkaji dan meneliti materi hukum keterbukaan informasi publik oleh ASN, pasca diberlakukannya undang-udang keterbukaan informsi publik. Johnny Ibrahim menyatakan bahwa nilai ilmiah suatu pembahasan dan pemecahan masalah terhadap legal issue yang diteliti sangat tergantung kepada cara pendekatan (approach) yang digunakan. ${ }^{6}$ Sesuai dengan tipe penelitian yang digunakan yaitu yuridis normatif maka pendekatan masalah yang dilakukan adalah:

a) Pendekatan Perundang-undangan (Statute Approach)

Pendekatan perundang-undangan merupakan suatu hal yang mutlak dalam penelitian yuridis normatif, karena yang akan diteliti adalah berbagai aturan hukum yang menjadi fokus sekaligus tema sentral suatu penelitian. ${ }^{7}$ Pendekatan perundangundangan dilakukan dengan menelaah semua undang-undang dan regulasi yang bersangkut paut dengan isu hukum yang sedang ditangani, ${ }^{8}$ isu tersebut adalah

5 Soerjono Soekanto. (2008). Pengantar Penelitian Hukum, Jakarta: Penerbit Universitas Indonesia. p. 52.

96 Johnny Ibrahim. (2006). Teori dan Metodologi Penelitian Hukum Normatif. Malang: Bayumedia Publishing, p. 299.

97 Ibid. p. 302.

8 Peter Mahmud Marzuki. (2005). Penelitian Hukum. Jakarta: Kencana Prenada Media Grup. P. 93. peraturan yang menyangkut keterbukaan informasi publik dan aparatur sipil negara.

b) Pendekatan Historis (Historical Approach)

Pendekatan historis dilakukan dalam kerangka pelacakan sejarah lembaga hukum dari waktu ke waktu. Pendekatan ini sangat membantu peneliti untuk memahami filosofi dari aturan hukum dari waktu ke waktu. Disamping itu, melallui pendekatan demikian penelitian ini juga dapat memahami perubahan dan perkembangan filosofi yang melandasi aturan hukum tersebut. ${ }^{9}$ Penelitian normatif yang menggunakan pendekatan sejarah memungkinkan seorang peneliti untuk memahami hukum secara lebih mendalam tentang suatu pengaturan hukum tertentu sehingga dapat memperkecil kekeliruan, baik dalam pemahaman maupun penerapan suatu lembaga atau ketentuan hukum tertentu. ${ }^{10}$

c) Pendekatan Kasus (Case Approach)

Berbeda dengan penelitian sosial11, pendekatan kasus (case approach), dalam penelitian normatif bertujuan untuk mempelajari penerapan norma-norma atau kaidah hukum yang dilakukan dalam praktik hukum.12 Pendekatan kasus dilakukan untuk melihat beberapa contoh kasus keterbukaan informasi publik oleh ASN. Pendekatan kasus (case approach) tidak sama dengan studi kasus (case study). Dalam pendekatan kasus beberapa kasus ditelaah untuk dijadikan referensi bagi suatu isu hukum. Sedangkan studi kasus (case study), adalah suatu studi terhadap kasus-kasus tertentu dilihat dari berbagai aspek hukum. ${ }^{13}$

9 Ibid, p. 126

10 Satjipto Raharjo, Op.cit, p. 332.

11 Marnasse Malo dan Sri Trisnongtias. (1997) Metode Penelitian Masyarakat. Jakarta: Pusat Antara Universitas Ilmu-Ilmu Sosial Unversitas Indonesia, p. 19.

12 Johnny Ibrahim. Op.cit, p. 321.

101 Peter Mahmud Marzuki. Op.cit, p. 94. 


\section{Pembahasan}

\subsection{Sejarah Lahirnya Undang-Undang Keterbukaan Informasi Publik Di Indonesia}

Informasi menyapa kita, nyaris setiap saat. Lewat media massa atau bahkan obrolan di pinggir jalan. Tapi tidak cukup banyak masyarakat yang secara sadar melebarkan pemahamnnya tentang informasi memasuki wilayah kajian Hak Asasi Manusia (HAM) atau mengkaitkannya dengan isu-isu demokrasi. Isu yang menghubungkannya semua warga negara dengan haknya untuk memperoleh informasi dan berpartisipasi dalam pemerintahan. Hanya sedikit di antara masyarakat, kalau tidak mau disebut minoritas yang menyadari bahwa rakyat mempunyai hak atas informasi yang tak muncul di media atau pengumumanpengumaman resmi pemerintahan. Hanya sedikit diantara masyarakat, kalau tidak mau disebut minoritas yang menyadari bahwa rakyat mempunyai hak atas informasi yang tak muncul di media atau pengumumanpengumuman resmi pemerintah.

Sebenarnya, perdebatan panjang mengenai arti penting informasi yang dalam konteks ini berupa dokumen yang dikuasai pejabat publik, sudah lama berlansung di sejumlah negara. Ruang rapat pemerintah dan parlemen Swedia sejak abad 17 sudah penuh dengan bekas-bekas angin yang berbunyi hak atas informasi. Tahun 1766, jauh sebelum Indonesia berdiri dan memperdebatkan penanganan untuk mantan dikatator yang menutup rapat informasi, sejumlah tokoh penting Swedia, sudah memikirkan arti penting adanya jaminan hukum bagi rakyat untuk mendapatkan informasi yang dikuasai penyelenggara negara. Tujuan sederhananya agar rakyat bukan hanya tahu informasi yang berada dalam genggaman mereka, tapi juga supaya rakyat bisa mengontrol jalnnya pemerintahan. Bukankah fungsi kontrol rakyat merupakan salah satu aspek penting dalam negara demokrasi? itu argumen utamanya. Sampai saat ini Swedia tidak menyusun undang-undang yang secara

14 Koalisi Untuk Kebebasan Informasi. (2009) Kebebasan Informasi Di Beberapa Negara, Jakarta: Lembaga Studi Pers dan Pembangunan, p. 2. khusus memberikan jaminan kebebasan atas informasi. Jaminan atas akses informasi publik diatur dalam Undang-Undang Kebebasan Pers, yang salah satu poin pentingnya menggarisbawahi hak bagi para jurnalis untuk mendapatkan informasi publik. Informasi yang dikuasai pejabat publik. Informasi yang berkaitan lansung dengan kelansungan hidup warga negara Swedia. ${ }^{14}$ Keberadaan undangundang tersebut menandai perjuangan masyarakat dunia untuk mengetahui yang dikuasai oleh penguasa.

Tapi apa memang benar hak atas informasi itu sangat diperlukan? Pertanyaan lainnya, apa hak ini memang sangat diperlukan oleh rakyat Indonesia yang mungkin lebih membutuhkan jaminan hak atas pekerjaan, rumah atau hakhak sipil dan politik. Pertanyaan itu harus terus dikemukakan karena kenyataan selintas membuktikan bahwa jaminan hak atas informasi baru belakangan menjadi perhatian sebagai masyarakat kalangan Organisasi Non Pemerintah (Ornop). Perdebatan di media masih penuh dengan perjuangan kalangan Ornop menuntut hak atas pekerjaan, hak untuk mendapatkan kebebasan berpolitik, jauh dari penyiksaan atau pun tuntutan adanya peradilan yang fair. Perjuangan untuk menciptakan adanya jaminan atas hak atas informasi bisa jadi memang kurang sexy. Kurang memikat. Pertanyaan lebih lanjut yang mungkin harus diajukan ialah mengapa perlu ada suatu undang-undang khusus yang mengatur hak atas informasi. Bukankah Deklarasi HAM dan Konvenan hak-hak sipil dan Politik sudah mengatur jaminan atas informasi. Kedua hukum internasional itu, jika keduanya mau ditafsirkan sebagai hukum internasional lepas dari perdebatan mengenai kedudukan hukum dari Deklarasi dan Konvenan yang hingga kini masih berlansung, dalam prakteknya tidak punya daya ikat bagi rejim yang tengah berkuasa tanpa adanya suatu peraturan khusus yang memberikan jaminan hak atas informasi. ${ }^{15}$ Apalagi bagi Indonesia

15 Ibid. p. 3-4. 
yang hingga kini belum meratifikasi Konvenan Hak-Hak Sipil dan politik.

Era keterbukaan yang mengiringi Reformasi 1998 semakin menimbulkan kesadaran akan terbukanya akses informasi dari berbagai kalangan. Secara khusus, keterbukaan akses menuju informasi publik diperlukan oleh mereka yang berkecimpung dalam bidang lingkungan, gerakan antikorupsi, hak asasi manusia, dan pers yang sering mengalami kesulitan dalam mengakses berbagai informasi dari lembaga pemerintah, dengan dalih rahasia negara. Meski demikian, keterbukaan informasi untuk publik telah tercantum dalam beberapa peraturan yang disahkan sebelum era reformasi, seperti: Undang-Undang No. 23 Tahun 1997 tentang Pengelolaan Lingkungan Hidup Setiap orang mempunyai hak atas informasi lingkungan hidup yang berkaitan dengan peran dalam pengelolaan lingkungan hidup (Pasal 5 Ayat 2) dan Undang-Undang No. 24 Tahun 1992 tentang Penataan Ruang Setiap orang berhak untuk mengetahui rencana tata ruang (Pasal 4, Ayat 2, Butir a).

Tiga isu besar yang mendorong lahirnya kesadaran atas kebutuhan informasi adalah upaya pemberantasan korupsi, penegakan hak asasi manusia, dan tata kelola pemerintah yang baik (good governance). Salah satu kasus riil yang memicu kesadaran itu adalah gugatan Wahana Lingkungan Hidup terhadap Inti Indorayon Utama dan lima instansi pemerintah berkaitan dengan hak publik atas informasi lingkungan hidup. Berangkat dari diskusidiskusi kecil, beberapa aktivis lembaga swadaya masyarakat pada awal masa-masa reformasi membentuk Koalisi Masyarakat Sipil untuk Kebebasan Memperoleh Informasi Publik. Gagasan akan kebebasan masyarakat untuk memperoleh informasi publik perlu dijamin karena merupakan bagian tidak terpisahkan dari penataan dan reformasi di berbagai sektor kehidupan, serta kebebasan mengakses informasi merupakan syarat bagi penyelenggaraan tata pemerintahan yang baik menjadi dasar gagasan yang dituangkan dalam

16 Dhoho A. Sastro (et-al). (2010) Mengenal UndangUndang Keterbukaan Informasi Publik. Jakarta: Lembaga Bantuan Hukum Masyarakat, p. 1-2. naskah RUU Kebebasan Memperoleh Informasi Publik (KMIP). Pada Program Pembangunan Nasional 2000 - 2005, pentingnya RUU KMIP mulai disinggung. Oleh karena Pemerintah dan Dewan Perwakilan Rakyat sudah menyadari pentingnya keterbukaan informasi, Koalisi mulai mengkomunikasikan RUU KMIP secara resmi ke DPR pada Agustus 2000. Pada Maret 2002 DPR menyetujui RUU KMIP sebagai RUU usul inisiatif. 16

Adapun pokok-pokok pikiran yang menjadi dasar lahirnya UU KIP. Usul Inisiatif tersebut adalah sebagai berikut: 1) Bahwa kebebasan memperoleh Informasl publik merupakan hak asasi manusia dan merupakan salah satu ciri terpenting dalam negara demokrasi untuk mewujudkan pemerintahan yang terbuka; 2)Bahwa kebebasan memperoleh informasi publik merupakan elemen penting untuk mengoptimalkan pengawasan publik terhadap pelaksanaan roda organisasi pemerintahan dan lembaga-Iembaga negara lainnya karena akan mampu mendorong pemerintahan yang akuntabilitas sehingga mampu pula meningkatkan kompetensi dan efisiensi. Bahwa didalam rangka menumbuhkan masyarakat dan pemerinthaan yang terbuka dibutuhkan pengembangan norma hukum yang dapat mempercepat aktualisasi dari hak anggota masyarakat untuk memperoleh informasi publik; 4) Bahwa hak untuk memperoleh informasi publik sesungguhnya telah dijamin dalam Pasal 28 F Undang-Undang Dasar 1945 dan ditegaskan kembali dalam Ketetapan MPRRI No. XVII/MPR/1998 tentang Hak Asasi Manusia (HAM) Pasal 20 dan Pasal 21, serta peraturan perundang-undangan lainnya yang berkaitan dengan kebebasan memperoleh informasi publik. Namun dalam prakteknya masih terdapat benturan dengan peratujan perundangan lainnya, sehingga memerlukan penjabaran yang lebih sesuai; 5) Bahwa informasi yang dimiliki pemerintah kadangkala digunakan untuk tujuan-tujuan yang melanggar hak asasi manusia. Dengan demikian kita perlu membuat peratuan perundang-undangan khusus yang mengatur 
tentang kebebasan memperoleh informasi publik. ${ }^{17}$

Pengajuan usul rancangan undang-undang ini berkaitan dengan salah satu aspek pembangunan hukum nasionai, yaitu pembangunan materi hukum yang tertulis. Dalam kaitan dengan hal tersebut, kami mencermati bahwa berbagai permasalahan faktual yang kita alami pada saat ini seperti tingkat hutang, kemiskinan, dan pengangguran yang tinggi, pelanggaran hak asasi manusia yang tidak terungkap, pengelolaan lingkungan hidup yang tidak efektif sampai terjadinya banjir tidak terlepas dari permasalahan struktural yaitu ketiadaan pemerintahan yang terbukan dan demokratis (good governance). Good governance adalah suatu sistem dimana para pemangku kepentingan (stakeholders) yang ada dalam suatu negara yaitu, penyelenggara negara, masyarakat sipil, dan sektor swasta memiliki kekuatan yang relatif seimbang, sehingga mekanisme check and balances dapat berjalan dengan efektif diantara ketiganya. Dalam menciptakan kondisi demikian salah satu pilar yang paling penting adalah mewujudkan pemerintahan terbuka (good goverment). ${ }^{18}$

Pemerintahan terbuka adalah penyelenggaraan pemerintahan dalam mengelola sumber daya publik yang dilakukan secara transparan partisipatoris sejak pengambilan keputusan, pelaksanaan sampai dengan penilaian kinerja suatu badan publik. Untuk dapat mewujudkan hal tersebut, maka pemerintahan terbuka mensyarakatkan adanya jaminan terhadap 6 (enam) hak-hak publik, yaitu; (1) hak untuk memantau perilaku pejabat publik dalam menjalankan peran publiknya (right to observe); (2) hak untuk memperoleh informasi (right to information); hak untuk terlibat dan berpartisipasi dalam proses pembentukan kebijakan publik (right to participate); (4) hak untuk dilindungi sebagai saksi, informan, dan pelapor dalam mengungkap fakta dan kebenaran, (5) hak untuk', berekspresi (freedom

17 Risalah Perundang-Undangan Keterbukaan Informasi Publik, p. 1. of expression) yang salah satunya terwujud, dalam kebebasan pers, dan (6) hak untuk mengajukan keberatan terhadap peno!akan atau tidak dijaminnya hak-hak 1, 2, 3, 4 dan 5. Upaya mewujudkan pemerintahan terbuka melalui jaminan akses informasi publik dapat dilihat sebagai upaya proaktif untuk mencegah praktek korupsi, kolusi dan nepotisme dalam mengelola sumber daya publik yang kini dipercaya sebagai penyebab utama dari munculnya krisis multi dimensional. Upaya pencegahan praktek Korupsi, Kolusi dan Nepotisme (KKN), melalui perwujudan pemerintahan yang terbuka bahkan lebih strategis dibandingkan dengan upaya pemberantasan dengan cara menghukum (represif). Manfaat kebebasan memperoleh informasi disamping untuk menciptakan pemerintahan yang bersih, efisien, mampu mencegah praktek KKN, sekaligus juga untuk meningkatkan kualitas partisipasi masyarakat dalam perumusan kebijakan publik (publik policy making process), dan meningkatkan kualitas pengawasan publik. Tanpa informasi, mustahil bagi seseorang untuk dapat berpartisipasi, mengungkapkan fakta dan kebenaran serta berekpresi secara efektif dan subtansial. ${ }^{19}$ Pada akhirnya, transparansi dan partisipasi publik yang luas dalam pengelolaan sumber daya publik juga akan sangat berpengaruh terhadap tingkat kepercayaan publik terhadap penyelenggara negara, suatu hal lain yang merupakan permasalahan utama kita saat ini.

Faktor lain yang mendasari perlu adanya Undang-undang ini, karena walaupun selama ini telah terdapat setidaknya 11 undangundang dan 3 (tiga) Peraturan Pemerintah yang secara normatif telah memberikan jaminan terhadap hak masyarakat untuk mendapatkan informasi. Namun sayangnnya jaminan tersebut pada prakteknya tidak berarti, sebab: 1) Budaya ketertutupan dalam penyelenggaraan negara yang sudah dikembangkan sejak jaman penjajahan; 2) Jaminan hukum akses informasi publik yang

\footnotetext{
18 Penjelasan Pengusul Usul Rancangan UndangUndang Usul Inisiatif Tentang Kebebasan Memperoleh Informasi Publik, p. 1.

19 Ibid. p. 2.
} 
ada dalam berbagai peraturan perundangundangan sebagaimana disebutkan di atas tidak komprehensif, tidak rinci dan tidak mempunyai daya penegakan (enforceability) serta bersifat umum dalam artian tidak jelas informasi mana yang bebas untuk dapat diakses oleh masyarakat serta informasi mana yang dapat dikecualikan secara ketat; 3) Selain itu berbagai peraturan perundang-undangan tersebut juga tidak mengatur mekanisme yang jelas bagi masyarakat untuk mengakses informasi publik secara cepat, tepat waktu, murah, dan sederhana, tidak diatur juga lembaga apa yang berwenang untuk menyelesaikan sengketa apabila ada perbedaan pandangan mengenai informasi yang dapat diakses dan tidak, tidak diatur limitasi jangka waktu bagi informasi yang tidak dapat diakses oleh masyarakat; 4) Berbagai permasalahan di atas masih ditambah lagi dengan kenyataan, buruknya sistem pengelolaan dan pelayanan informasi di badan-badan publik. Keseluruhan permasalahan tersebut mengakibatkan mustahil bagi masyarakat' untuk dapat mengakses informasi secara tepat, waktu, murah dan dengan prosedur yang sederhana. Dengan diajukannya RUU Usul Inisiatif tentang kebebasan Memperoleh Informasi Publik, maka semua peraturan yang berkaitan dengan informasi publik akan dirangkum dalam RUU ini sehingga terdapat kejelasan tentang jaminan akses informasi publik bagi masyarakat.

Secara yuridis, pengajuan usul rancangan undang-undang ini selarah dengan amanat dari UUD RI Tahun 1945, TAP MPR RI Nomor XVII/MPR/1998 tentang Hak Asasi Manusia, TAP MPR Nomor VIII/MPR.2001 tentang Rekomendasi Arah Kebijakan Pemberantasan dan Pencegahan Korupsi, Kolusi dan Nepotisme, serta Undnag-Undang Nomor 25 Tahun 2000 tentang Program Pembangunan Nasional (UU 25/2000). Sedangkan Pasal 28 F UUD 1945 menyatakan Setiap orang berhak untuk berkomunikasi dan memperoleh informasi untuk mengembangkan pribadi dan lingkungan sosialnya, serta berhak untuk mencari, memperoleh, memiliki, menyimpan, mengolah, dan menyampaikan informasi dengan menggunakan segala jenis saluran yang tersedia. Sementara Pasal 20 dan 21 Ketetapan MPR-RI No. XVII/MPR/1998 tentang Hak-hak Asasi Manusia, menyebutkan: Pasal 20, menyatakan Setiap orang berhak untuk berkomunikasi dan memperoleh informasi untuk mengembangkan pribadi dan lingkungan sosialnya. Pasal 21, menyatakan setiap orang berhak untuk mencari, memperoleh, memiliki, menyimpan, mengolah, dan menyampaikan informasi dengan menggunakan segala jenis saluran yang tersedia." Dalam Pasal 2 Butir 6 TAP MPR No. VIIl/MPR/2001 tentang Rekomendasi Arah Kebijaksanaan Pemberantasan dan Pencegahan KKN disebutkan bahwa: Arah Kebijaksanaan pemberantasan KKN membentuk UU beserta peraturan pelaksananya untuk membantu mempercepat dan efektivitas pelaksanaan pemberantasan dan pencegahan korupsi yang meliputi: a) Komisi Pemberantasan Tindak Pidana Korupsi; b) Perlindungan Saksi dan Korban; c) Kejahatan terorganisir; d) Kebebasan Mendapatkan Informasi; e) Etika Pemerintahan; f) Kegiatan Pencucian Uang; g) Ombudsman. Selain itu pembuatan UU ini juga dimandatkan dalam Matriks Kebijakan Program Pembangunan Hukum di bawah indikator kinerja politik UU 25/2000. Tahun 2000-2004 disebutkan bahwa salah satu undang-undag yang harus diundangkan adalah undang-undang tentang Transparansi dan Kebebasan Memperoleh Informasi.

Materi pokok yang terdapat dalam rancangan undang-undang ini. Tetapi sebelumnya kami akan sampaikan terlebih dahulu prinsipprinsip penting yang dimuat dalam rancangan undang-undang ini agar pemerintahan terbuka yang kita cita-citakan dapat terwujud:20 1) undang-undang Kebebasan Memperoleh Informasi Publik bersifat menjadi acuan bagi ketentuan-ketentuan mengenai akses informasi publik yang terdapat di dalam undang-undang lain serta merupakan perangkat koordinasi dan harmonisasi di antara berbagai peraturan perundang-undangan yang terkait dengan informasi publik; 2) Adanya jaminan bagi hak

20 Risalah Perundang-Undangan Tentang Keterbukaan Informasi Publik, p. 5. 
bagi setiap orang untuk mengetahui, melihat, dan mendapatkan. informasi tanpa memerlukan alasan yang melatarbelakangi permintaan; 3) Akses yang bersifat sederhana, biaya ringan, cepat dan tepat waktu; 4) Informasi yang dapat diakses publik bersifat utuh, akurat, benar dan riable; 5) Maximum access and limited exemption; pada dasarnya seluruh informasi publik bersifat terbuka walaupun demikian tentunya tidak semua informasi dapat diakses publik. Oleh karenanya ada mekanisme pengecualian yang hanya dapat dilakukan secara ketat dan terbatas, selain itu diakui juga mekanisme menimbang kepentingan publik untuk membuka atau menutup suatu informasi yang dikecualikan; 6) Kewajiban badan publik untuk mengumumkan ianformasi yang dimilikinya secara berkala, tanpa adanya permintaaan (akses informasi proaktif); 7) Kewajiban badan publik untuk menyediakan informasi tertentu setiap saat termasuk didalamnya kewajiban badan publik membuat daftar seluruh informasi yang berada di bawah penguasanya; 8) Penyelesaian sengketa secara cepat dan murah, oleh badan yang berkompeten dan independen; 9) Ancaman hukuman bagi mereka yang dengan sengaja menghambat akses informasi publik; 10) Perlindungan terhadap informan dan pejabat publik yang beritikad baik.

Dalam rangka menciptakan pemerintahan yang terbuka, maka dalam RUU Inl diusulkan unsur mengatur seluruh lingkup hak masyarakat atas informasi, yaitu mencakup (1) hak untuk melihat informasi (the right to Inspecf), (2) hak untuk menghadiri pertemuan publik (the right to attend public meeting), (3) hak untuk mengetahui (the right to know/the right to Information), (4) hak untuk mendapatkan salinan informasi (the right to obtain a copy), (5) hak untuk diberitahu atau diinformasikan mengenai suatu hal (the right to be informed), dan (6) hak untuk menyebarluaskan informasi (the right to disseminate information). Dari amanat UUD 1945, Ketetapan Majelis Permusyawaratan Rakyat Republik Indonesia (TAP MPR) dan Program Pembangunan Nasional tersebut jelas kiranya bahwa rancangan undang-undang ini sangat penting untuk segera dibahas dan direalisasikan.

Empat kali amandemen UUD 1945 telah membawa perubahan penting dalam bidang hak asasi manusia. Masalah HAM diatur dan dimasukkan ke dalam bab tersendiri. Masuknya HAM bukan semata karena desakan masyarakat internasional, melainkan karena merupakan syarat suatu negara hukum. Hak asasi manusia sering dijadikan sebagai indikator untuk mengukur tingkat peradaban, demokrasi, dan kemajuan suatu bangsa. Salah satu rumusan HAM adalah pengakuan hak setiap orang untuk berkomunikasi dan mendapatkan informasi, sebagaimana dinyatakan dalam Pasal 28 F UUD 1945, yang menyatakan bahwa setiap orang berhak untuk berkomunikasi dan memperoleh informasi untuk mengembangkan pribadi dan lingkungan sosialnya, serta berhak untuk mencari, memperoleh, memiliki, menyimpan, mengelola, dan menyampaikan informasi dengan menggunakan segala jenis saluran yang tersedia. Dalam proses pembahasan di sidangsidang MPR, Pasal 28 F kurang mendapat pembahasan dibandingkan dengan pasal-pasal HAM lainnya. Ini bisa berarti bahwa mayoritas anggota MPR tidak berkeberatan atas masuknya hak atas informasi ke dalam UUD 1945.21 Dari rumusan tersebut bisa kita pilah perbuatan apa saja yang dilindungi Konstitusi berkaitan dengan informasi, yaitu: (a) Mencari; (b) Memperoleh; (c) Memiliki; (d) Menyimpan; (e) Mengelola; dan (f) Menyampaikan.

Jika ditelusuri lebih jauh, ketentuan Pasal $28 \mathrm{~F}$ UUD 1945 sebenarnya berasal dari Ketetapan MPR Nomor XVII/MPR/1998 tentang Hak Asasi Manusia. Namun, TAP MPR ini kemudian dicabut dan dinyatakan tidak berlaku melalui TAP MPR Nomor I/MPR/2003. Apakah dengan pencabutan ini pasal mengenai HAM dalam TAP Nomor XVII tidak berlaku? TAP Nomor I/MPR/2003 meninjau ulang materi dan status sebanyak 139 ketetapan MPR sebelumnya. TAP Nomor XVII dinyatakan tidak berlaku karena materinya sudah diatur dan diangkat ke dalam UUD 1945. Sebelum diangkat menjadi norma

21 Dhoho A. Sastro. Op.cit. p. 8-9. 
konstitusional, Pasal 20 dan Pasal 21 TAP MPR Nomor XVII/MPR/1998 terlebih dahulu dituangkan ke dalam Pasal 14 Undang-Undang Nomor 39 Tahun 1999 tentang Hak Asasi Manusia (UU HAM). Pasal 14 UU HAM merumuskan: (1) Setiap orang berhak untuk berkomunikasi dan memperoleh informasi untuk mengembangkan pribadi dan lingkungan sosialnya; (2) Setiap orang berhak untuk mencari, menyimpan, mengolah, dan menyampaikan informasi dengan menggunakan segala jenis saluran yang tersedia. Ketika dimasukkan dan diangkat ke dalam UUD 1945, kedua ayat tersebut disatukan menjadi satu nafas. Pasal 28 F UUD 1945 sebenarnya tidak secara eksplisit memerintahkan perlunya dibuat undangundang yang mengatur akses terhadap informasi. Perintah itu secara tidak langsung dimuat dalam Pasal 28 I ayat (5) yang menyatakan bahwa untuk menegakkan dan melindungi hak asasi manusia sesuai dengan prinsip negara hukum yang demokratis, maka pelaksanaan hak asasi manusia dijamin, diatur, dan dituangkan dalam peraturan perundangundangan. Pasal ini memungkinkan HAM diatur dalam berbagai bentuk peraturan perundang-undangan. ${ }^{22}$

UU KIP mengacu pada Pasal 28 F UUD 1945. dan ditandatangani oleh Presiden pada saat itu Susilo Bambang Yudhoyono pada tanggal 30 April 2008, dan berlaku dua tahun setelah diundangkan. UU KIP adalah contoh ius constituendum. Sebelum UU KIP lahir, hak atas informasi diakui secara parsial dalam berbagai peraturan perundang-undangan. Hak atas informasi tata ruang (Undang-Undang Penataan Ruang dan Peraturan Pemerintahan Nomor 69 tahun 1996). ${ }^{23}$ Antara lain: 1) Hak atas informasi lingkungan hidup (UndangUndang Nomor 32 Tahun 2009); 2) Hak atas informasi yang benar, jelas, dan jujur mengenai kondisi dan jaminan barang dan/atau asa (Undang-Undang Nomor 8 Tahun 1999 tentang Perlindungan Konsumen); 3) Hak mencari, memperoleh, memberikan informasi tentang penyelenggaraan negara, serta hak mendapat

\footnotetext{
$22 \mathrm{Ibid}$, p. 9.

${ }^{23} \mathrm{Ibid}, \mathrm{p} .10-11$.
}

perlindungan hukum dalam mencari, memperoleh dan memberikan informasi tersebut (UU Nomor 28 Tahun 1999 tentang penyelenggaraan Negara yang Bersih dan Bebas dari KKN); 4) Hak atas catatan/rekaman pemakaian jasa telekomunikasi (UU Nomor 36 Tahun 1999 tentang Telekomunikasi); 5) Hak masyarakat untuk melakukan kegiatan untuk mengembangkan kemerdekaan pers dan menjamin hak memperoleh informasi yang diperlukan (UU Nomor 40 Tahun 1999 tentang Pers).

\subsection{Dampak UU KIP Terhadap Keterbukaan Informasi Di Indonesia}

Jika dilihat dari konteks hubungan antara pemerintah dan warganegaranya, secara garis besar implikasi penerapan UU KIP tersebut melekat pada dua pihak, yaitu penyelenggara pemerintahan dan masyarakat atau publik. Pada pihak penyelenggara pemerintahan, ada beberapa implikasi penerapan UU KIP, seperti kesiapan lembaga pemerintah untuk mengklasifikasikan informasi publik menjadi informasi yang wajib disediakan dan diumumkan secara berkala, informasi yang wajib diumumkan serta merta, dan informasi yang wajib disediakan. Implikasi lain bagi pemerintah pada saat UU KIP diterapkan nampaknya adalah semua urusan tata kepemerintahan berupa kebijakan-kebijakan publik, baik yang berkenaan dengan pelayanan publik, pengadaan barang dan jasa pemerintah, penyusunan anggaran pemerintah, maupun pembangunan harus diketahui oleh publik, termasuk juga isi keputusan dan alasan pengambilan keputusan kebijakan publik serta informasi tentang kegiatan pelaksanaan kebijakan publik tersebut beserta hasil-hasilnya harus terbuka dan dapat diakses oleh publik. Sehingga ada konsekuensi bahwa aparatur pemerintahan atau badan publik harus bersedia secara terbuka dan jujur memberikan informasi yang dibutuhkan publik, hal seperti ini bagi sebagian atau mungkin seluruhnya dari aparat pemerintah atau badan publik merupakan hal yang belum atau tidak terbiasa untuk dilakukan. ${ }^{24}$ Tetapi implikasi ini beserta

24 Nunuk Febrianginsih. (2012). “Keterbukaan Informasi Publik Dalam Pemerintahan Terbuka 
konsekuensinya tetap harus dihadapi sejalan dengan penerapan UU KIP.

Implikasi penerapan UU KIP terhadap masyarakat atau publik adalah terbukanya akses bagi publik untuk mendapatkan informasi yang berkaitan dengan kepentingan publik, terbukanya akses bagi publik untuk berpartisipasi aktif dalam proses pembuatan kebijakan publik, termasuk didalamnya akses untuk pengambilan keputusan dan mengetahui alasan pengambilan keputusan yang berkaitan dengan kepentingan publik. Kemudian implikasi yang dipandang sangat penting adalah dengan adanya penerapan UU KIP ini daya kritis masyarakat atau publik terhadap kinerja penyelenggaraan pemerintahan terutama pelayanan publik semakin meningkat dan diperkirakan tingkat penilaian atau pengaduan masyarakat atau publik terhadap kualitas layanan publik juga semakin meningkat. Implikasi lain sejalan dengan meningkatnya daya kritis masyarakat, adalah peningkatan pengetahuan masyarakat mengenai hak-hak mereka dalam pelayanan publik yang disediakan oleh lembaga pemerintah. Sehingga apabila suatu saat terjadi ketimpangan atau permasalahan dalam pelayanan publik, maka akan banyak pengaduan masyarakat berkaitan dengan kualitas pelayanan publik tersebut. Meningkatnya pengetahuan masyarakat dan keingintahuan masyarakat terkait proses penyelenggaraan pemerintahan, juga merupakan implikasi yang akan dihadapi dalam penerapan UU KIP. Dan hal tersebut dapat meningkatkan minat dan keinginan masyarakat untuk berperan serta dan berpartisipasi dalam proses penyelenggaraan pemerintahan sesuai dengan kapasitas masingmasing. Dengan melihat berbagai implikasi yang telah disebutkan di atas baik yang dihadapi oleh masyarakat maupun penyelenggara pemerintahan, maka mbul suatu pertanyaan sejauh mana kesiapan

Menuju Tata Pemerintahan Yang Baik". Jurnal Rechtvinding. 1 (1). p. 146.

25 Ridwan Mansyur. (2015) “Keterbukaan Informasi Di Peradilan Dalam Rangka Implementasi Integritas Dan Kepastian Hukum". Jurnal Hukum dan Peradilan, 4 (1). 87. lembaga pemerintah dalam mengantisipasi berbagai implikasi tersebut, paling tidak adalah selama satu tahun sejak UU KIP efektif diterapkan ada langkah-langkah baik itu beberapa kebijakan maupun penguatan kelembagaan pemerintah daerah untuk meminimalkan benturan yang terjadi akibat implikasi penerapan UU KIP.

Keterbukaan informasi publik adalah salah satu amanat dari UU KIP, dimana keterbukaan informasi publik merupakan sarana untuk mengoptimalkan pengawasan publik terhadap penyelenggaraan negara guna mewujudkan kepemerintahan yang baik (good governance). Hal ini dilihat dari jumlah 64 pasal yang pada intinya memberikan kewajiban kepada setiap Badan Publik untuk membuka akses bagi setiap pemohon informasi publik, kecuali beberapa informasi tertentu. Selain itu UU KIP juga ditopang oleh Undang-Undang nomor 25 tahun 2009 tentang Pelayanan Publik yang mengatur tentang prinsip-prinsip pemerintahan yang baik yang merupakan efektivitas fungsi-fungsi pemerintahan itu sendiri. Pelayanan publik yang dilakukan oleh pemerintahan atau koporasi yang efektif dapat memperkuat demokrasi dan HAM, mempromosikan kemakmuran ekonomi, kohese sosial, mengurangi kemiskinan, meningkatkan perlindungan lingkungan, bijak dalam pemanfaatan sumber daya alam, memperdalam kepercayaan pada pemerintahan dan administrasi publik. ${ }^{25}$

Perkembangan keterbukaan informasi di Indonesia saat ini telah bergerak dari sekedar keberadaan jaminan hukum ke arah implementasi. Namun berbagai hasil studi menunjukkan, implemetasinya belum sepenuhnya sesuai dengan tujuan yang diharapkan UU KIP. ${ }^{26}$ Hak atas informasi ini secara tegas diatur Pasal 4 UU KIP, yang menyebutkan: (1) Setiap Orang berhak memperoleh Informasi Publik sesuai dengan ketentuan Undang-Undang ini; (2) Setiap

26 Fauzi Syam. (2015) "Hak Atas Informasi Dan Legal Standing Para Pihak Dalam Sengketa Informasi Di Komisi Informasi". Jurnal Inovatif. 8 (1). p. 43. 
Orang berhak: a, melihat dan mengetahui Informasi Publik; b, menghadiri pertemuan publik yang terbuka untuk umum untuk memperoleh Informasi Publik; c, mendapatkan salinan Informasi Publik melalui permohonan sesuai dengan UndangUndang ini; dan/atau d, menyebarluaskan Informasi Publik sesuai dengan peraturan perundang- undangan; (3) Setiap Pemohon Informasi Publik berhak mengajukan permintaan Informasi Publik disertai alasan permintaan tersebut; (4) Setiap Pemohon Informasi Publik berhak mengajukan gugatan ke pengadilan apabila dalam memperoleh Informasi Publik mendapat hambatan atau kegagalan sesuai dengan ketentuan Undang-Undang ini.

Ada beberapa pokok pikiran terkait dengan rumusan Pasal 4 tersebut di atas. Pertama, jaminan hak atas informasi yang diatur dalam UU KIP demikian luas. Lingkup hak atas informasi bukan hanya berbentuk dokumen saja, melainkan juga tindakan- tindakan tertentu yang dilakukan badan publik agar masyarakat dapat mengakses informasi yang dibutuhkan. Lebih lanjut, UU KIP juga memberikan mandat agar badan publik secara proaktif memberikan akses kepada publik tanpa adanya permintaan terlebih dahulu, khususnya untuk informasi-infomasi tertentu. Kedua, hak memperoleh informasi harus dipandang melekat dengan hak untuk mengajukan keberatan/gugatan melalui lembaga penyelesaian sengketa yang ditunjuk (atasan, Komisi Informasi, maupun pengadilan) apabila dalam memperoleh informasi mendapat hambatan atau kegagalan. Hak mengajukan keberatan/gugatan ini merupakan akses masyarakat terhadap keadilan (access to justice). Pasal ini merupakan dasar untuk mengajukan banding administrasi dan hak gugat (legal standing) bagi masyarakat ke pengadilan. ${ }^{27}$

Pasal 1 angka 1 UU KIP mendefinisikan informasi sebagai berikut: Informasi adalah keterangan, pernyataan, gagasan, dan tandatanda yang mengandung nilai, makna dan pesan, baik data, fakta maupun penjelasannya

27 Henri Subagiyo. (2012). Anotasi Undang-Undang Nomor 14 tahun 2008 tentang Keterbukaan Informasi yang dapat dilihat, didengar, dan dibaca yang disajikan dalam berbagai kemasan dan format sesuai dengan perkembangan teknologi informasi dan komunikasi secara elektronik ataupun non-elektronik. Kemudian Pasal 1 angka 2 UU KIP mendefinisikan informasi publik sebagai berikut: Informasi Publik adalah informasi yang dihasilkan, disimpan, dikelola, dikirim, dan/atau diterima oleh suatu Badan Publik yang berkaitan dengan penyelenggara dan penyelenggaraan negara dan/atau penyelenggara dan penyelenggaraan Badan Publik lainnya yang sesuai dengan UndangUndang ini serta informasi lain yang berkaitan dengan kepentingan publik.

Dari definisi ini dapat diambil kesimpulan bahwa: 1) Informasi yang wajib disediakan, diberikan, dan diumumkan kepada masyarakat adalah seluruh informasi yang dibuat atau yang dikuasai oleh Badan Publik yang berkaitan dengan penyelenggara negara dan penyelenggaraan negara. Yang dimaksud dengan informasi terkait penyelenggara negara adalah informasi terkait dengan organ dalam arti statis misalnya keberadaan, pengurus, maksud dan tujuan, dsb. Sementara informasi yang terkait dengan penyelenggaraan negara adalah informasi publik yang merupakan hasil dari pelaksanaan fungsi-fungsi badan publik, misalnya laporan kegiatan dan kinerja badan publik, laporan keuangan, kebijakan-kebijakan yang dihasilkan, dan sebagainya. Mencakup pula informasi yang disediakan oleh individu dan Badan Privat untuk Badan Publik, dengan tetap tunduk pada rezim pengecualian (yang di antaranya melindungi privasi); 2) Informasi publik yang wajib disediakan, diberikan, dan diumumkan adalah informasi sebelum dan sesudah Undang-undang Keterbukaan Informasi Publik diundangkan. Hal ini merupakan konsekuensi logis dari frasa-frasa "dihasilkan, disimpan, dikelola, dikirim, dan/atau diterima" dalam definisi "Informasi Publik" dalam Pasal 1 angka 2 UU KIP; 3) Informasi yang belum final juga termasuk dalam lingkup informasi publik, selama informasi tersebut telah berada dalam sirkulasi antar badan publik; 4) Termasuk pula sebagai

Publik, Jakarta: Komisi Informasi Republik Indonesia. p. 99. 
informasi publik adalah seluruh informasi yang terkait dengan kepentingan publik. Jadi sepanjang adanya kepentingan publik dapat ditunjukkan hubungannya dengan informasi tersebut, maka ia dapat dikategorikan sebagai informasi publik. (Pasal 9 ayat (2) huruf a UU KIP). ${ }^{28}$ Jenis-jenis informasi dalam dalam UU KIP, adalah: a) Informasi yang wajib disediakan secara berkala; b) Informasi yang wajib disediakan setiap saat; c) Informasi yang wajib disediakan secara serta merta; d) Informasi yang dikecualikan.

Informasi yang wajib disediakan dan diumumkan secara berkala berdasarkan Pasal 9 menyatakan: (1) Setiap Badan Publik wajib mengumumkan Informasi Publik secara berkala; (2) Informasi Publik sebagaimana dimaksud pada ayat (1) meliputi: a, informasi yang berkaitan dengan Badan Publik; b, informasi mengenai kegiatan dan kinerja Badan Publik terkait; c, informasi mengenai laporan keuangan; dan/atau d, informasi lain yang diatur dalam peraturan perundang-undangan; (3) Kewajiban untuk memberikan dan menyampaikan Informasi Publik sebagaimana dimaksud pada ayat (2) dilakukan paling singkat 6 (enam) bulan sekali; (4) Kewajiban menyebarluaskan Informasi Publik sebagaimana dimaksud pada ayat (1), disampaikan dengan cara yang mudah dijangkau oleh masyarakat dan dalam bahasa yang mudah dipahami; (5) Cara-cara sebagaimana dimaksud pada ayat (4) ditentukan lebih lanjut oleh Pejabat Pengelola Informasi dan Dokumentasi di Badan Publik terkait; (6) Ketentuan lebih lanjut mengenai kewajiban Badan Publik memberikan dan menyampaikan Informasi Publik secara berkala sebagaimana dimaksud pada ayat (1), ayat (2), dan ayat (3) diatur dengan Petunjuk Teknis Komisi Informasi. Sedangkan informasi yang wajib diumumkan secara serta-merta dinyatakan dalam Pasal 10, bahwa: (1) Badan Publik wajib mengumumkan secara sertamerta suatu informasi yang dapat mengancam hajat hidup orang banyak dan ketertiban umum; (2) Kewajiban menyebarluaskan

28 Khairunnisa Kamaliah. (2015) “Implementasi Undang-Undang Nomor 14 Tahun 2008 Tentang Keterbukaan Informasi Publik Di Badan
Informasi Publik sebagaimana dimaksud pada ayat (1) disampaikan dengan cara yang mudah dijangkau oleh masyarakat dan dalam bahasa yang mudah dipahami.

Sedangkan informasi yang wajib tersedia setiap saat, dinyatakan dalam Pasal 11, yaitu: (1) Badan Publik wajib menyediakan Informasi Publik setiap saat yang meliputi: a, daftar seluruh Informasi Publik yang berada di bawah penguasaannya, tidak termasukinformasi yang dikecualikan; b, hasil keputusan Badan Publik dan pertimbangannya; c, seluruh kebijakan yang ada berikut dokumen pendukungnya; $d$, rencana kerja proyek termasuk di dalamnya perkiraan pengeluaran tahunan Badan Publik; e, perjanjian Badan Publik dengan pihak ketiga; $\mathrm{f}$, informasi dan kebijakan yang disampaikan Pejabat Publik dalam pertemuan yang terbukauntuk umum; g, prosedur kerja pegawai Badan Publik yang berkaitan dengan pelayanan masyarakat; dan/atau $h$, laporan mengenai pelayanan akses Informasi Publik sebagaimana diatur dalam Undang-Undang ini; (2) Informasi Publik yang telah dinyatakan terbuka bagi masyarakat berdasarkan mekanisme keberatan dan/atau penyelesaian sengketa sebagaimana dimaksud dalam Pasal 48, Pasal 49, dan Pasal 50 dinyatakan sebagai Informasi Publik yang dapat diakses oleh Pengguna Informasi Publik.; (3) Ketentuan lebih lanjut mengenai tata cara pelaksanaan kewajiban Badan Publik menyediakan Informasi Publik yang dapat diakses oleh Pengguna Informasi Publik sebagaimana dimaksud pada ayat (1) dan ayat (2) diatur dengan Petunjuk Teknis Komisi Informasi.

Pasal 17 UU KIP menyatakan mengenai informasi yang dikecualikan, yaitu: Setiap Badan Publik wajib membuka akses bagi setiap Pemohon Informasi Publik untuk mendapatkan Informasi Publik, kecuali: a) Informasi Publik yang apabila dibuka dan diberikan kepada Pemohon Informasi Publik dapatmenghambat proses penegakan hukum, yaitu informasi yang dapat: 1, menghambat proses penyelidikan dan penyidikan suatu

Perencanaan Pembangunan Daerah Kota Samarinda". Jurnal Ilmu Pemerintahan, 3 (2). p. 1116. 
tindak pidana; 2, mengungkapkan identitas informan, pelapor, saksi, dan/atau korban yang mengetahui adanya tindak pidana; 3, mengungkapkan data intelijen kriminal dan rencana-rencana yang berhubungan dengan pencegahan dan penanganan segala bentuk kejahatan transnasional; 4, membahayakan keselamatan dan kehidupan penegak hukum dan/atau keluarganya; dan/atau 5, membahayakan keamanan peralatan, sarana, dan/atau prasarana penegak hukum; b) Informasi Publik yang apabila dibuka dan diberikan kepada Pemohon Informasi Publik dapat mengganggu kepentingan perlindungan hak atas kekayaan intelektual dan perlindungan dari persaingan usaha tidak sehat; c) Informasi Publik yang apabila dibuka dan diberikan kepada Pemohon Informasi Publik dapat membahayakan pertahanan dan keamanan negara, yaitu: 1, informasi tentang strategi, intelijen, operasi, taktik dan teknik yang berkaitan dengan penyelenggaraan sistem pertahanan dan keamanan negara, meliputi tahap perencanaan, pelaksanaan dan pengakhiran atau evaluasi dalam kaitan dengan ancaman dari dalam dan luar negeri; 2 , dokumen yang memuat tentang strategi, intelijen, operasi, teknik dan taktik yang berkaitandengan penyelenggaraan sistem pertahanan dan keamanan negara yang meliputi tahap perencanaan, pelaksanaan dan pengakhiran atau evaluasi; 3, jumlah, komposisi, disposisi, atau dislokasi kekuatan dan kemampuan dalam penyelenggaraan sistem pertahanan dan keamanan negara serta rencanapengembangannya; 4 , gambar dan data tentang situasi dan keadaan pangkalan dan/atau instalasi militer; 5, data perkiraan kemampuan militer dan pertahanan negara lain terbatas pada segala tindakan dan/atau indikasi negara tersebut yang dapat membahayakan kedaulatan Negara Kesatuan Republik Indonesia dan/atau data terkait kerjasama militer dengan negara lain yang disepakati dalam perjanjian tersebut sebagai rahasia atau sangat rahasia; 6, sistem persandian negara; dan/atau 7 , sistem intelijen negara; d) Informasi Publik yang apabila dibuka dan diberikan kepada Pemohon Informasi Publik dapat mengungkapkan kekayaan alam Indonesia; e) Informasi Publik yang apabila dibuka dan diberikan kepada Pemohon Informasi Publik, dapat merugikan ketahanan ekonomi nasional: 1, rencana awal pembelian dan penjualan mata uang nasional atau asing, saham dan aset vital milik negara; 2, rencana awal perubahan nilai tukar, suku bunga, dan model operasi institusi keuangan; 3 , rencana awal perubahan suku bunga bank, pinjaman pemerintah, perubahan pajak, tarif, atau pendapatan negara/daerah lainnya; 4, rencana awal penjualan atau pembelian tanah atau properti; 5 , rencana awal investasi asing; 6 , proses dan hasil pengawasan perbankan, asuransi, atau lembaga keuangan lainnya; dan/atau 7, hal-hal yang berkaitan dengan proses pencetakan uang; f) Informasi Publik yang apabila dibuka dan diberikan kepada Pemohon Informasi Publik, dapat merugikan kepentingan hubungan luar negeri: 1, posisi, daya tawar dan strategi yang akan dan telah diambil oleh negara dalam hubungannya dengan negosiasi internasional; 2, korespondensi diplomatik antarnegara; 3, sistem komunikasi dan persandian yang dipergunakan dalam menjalankan hubungan internasional; dan/atau 4, perlindungan dan pengamanan infrastruktur strategis Indonesia di luar negeri; g) Informasi Publik yang apabila dibuka dapat mengungkapkan isi akta otentik yang bersifat pribadidan kemauan terakhir ataupun wasiat seseorang; h) Informasi Publik yang apabila dibuka dan diberikan kepada Pemohon Informasi Publik dapat mengungkap rahasia pribadi, yaitu: 1, riwayat dan kondisi anggota keluarga; 2, riwayat, kondisi dan perawatan, pengobatan kesehatan fisik, dan psikis seseorang; 3, kondisi keuangan, aset, pendapatan, dan rekening bank seseorang; 4, hasil-hasil evaluasi sehubungan dengan kapabilitas, intelektualitas, dan rekomendasi kemampuan seseorang; dan/atau 5, catatan yang menyangkut pribadi seseorang yang berkaitan dengan kegiatan satuan pendidikan formal dan satuan pendidikan nonformal; i) memorandum atau surat-surat antar Badan Publik atau intra Badan Publik, yang menurut sifatnya dirahasiakan kecuali atas putusan Komisi Informasi atau pengadilan; j) informasi yang tidak boleh diungkapkan berdasarkan Undang-Undang. 
UU KIP memilah informasi publik dalam dua kategori: Pertama, Informasi yang wajib disediakan dan diumumkan, terdiri atas: 1) Informasi yang Wajib Disediakan dan Diumumkan Secara Berkala (minimal $1 \times 6$ bulan) yaitu: a, Informasi yang berkaitan dengan Badan Publik; b, Kegiatan dan kinerja Badan Publik; c, Laporan keuangan; d, Informasi lain yang diatur dalam peraturan perundang- undangan, 2) Informasi yang Wajib Diumumkan Serta-Merta (mudah dijangkau dan mudah dipahami), yaitu: a, Mengancam hidup orang banyak. Misalnya, ancaman bencana alam tsunami, $b$, Menganggu ketertiban umum. Misalnya, tawuran di suatu tempat, kemacetan lalu lintas, 3) Informasi yang Wajib Tersedia Setiap Saat, yaitu: a, Daftar seluruh informasi publik yang berada di bawah penguasaannya minus info yang dikecualikan, b, Hasil keputusan Badan Publik dan pertimbangannya, c, Seluruh kebijakan yang ada berikut dokumen pendukungnya, $d$, Rencana kerja proyek, termasuk rencana pengeluaran tahunan, e, Perjanjian Badan Publik dengan pihak ketiga, f, Informasi yang disampaikan pejabat publik dalam pertemuan terbuka untuk umum, g, Prosedur kerja pegawai berkaitan dengan pelayanan publik, $h$, Laporan mengenai pelayanan akses informasi. $^{29}$

Kedua, Informasi yang dikecualikan pada hakikatnya adalah informasi publik, sehingga pengecualiannya tidak boleh bersifat permanen. Ukuran untuk menjadikan suatu informasi publik dikecualikan atau bersifat rahasia adalah: (1) Undang-undang; (2) kepatutan; dan (3) kepentingan umum. Ketiga parameter itu harus melalui uji konsekuensi: yakni pengujian oleh Badan Publik apakah membuka informasi itu tidak akan melindungi kepentingan yang lebih besar atau tidak, atau sebaliknya. Informasi yang dikecualikan meliputi informasi publik yang jika dibuka dan diberikan kepada pemohon: ${ }^{30}$

1) Dapat menghambat proses penegakan hukum: a, Menghambat proses penyelidikan atau penyidikan suatu tindak pidana. (Lihat KUHAP); b,

${ }^{29}$ Dhoho A. Sastro, Op.cit, p. 22.
Mengungkapkan identitas informan, pelapor, saksi, atau korban yang mengetahui tindak pidana. Namun, saksi dan korban berhak mendapatkan informasi mengenai perkembangan kasus dan informasi mengenai putusan pengadilan (Lihat Pasal 5 Ayat 1 UU 13/2006), c, Mengungkapkan data intelijen kriminal dan rencana yang berhubungan dengan pencegahan dan penanganan segala bentuk kejahatan transnasional. (Menurut Undang- Undang Tindak Pidana Pencucian Uang, dalam sidang pengadilan sekalipun saksi saksi, penuntut umum, hakim, dan orang lain yang bersangkutan dengan tindak pidana pencucian uang yang sedang dalam pemeriksaan dilarang menyebut nama atau alamat pelapor, atau hal-hal lain yang memungkinkan dapat terungkapnya identitas pelapor); d, Membahayakan keselamatan dan kehidupan penegak hukum dan/atau keluarganya; e, Membahayakan keamanan peralatan, sarana, dan prasarana penegakan hukum;

2) Mengganggu kepentingan perlindungan HKI dan perlindungan dari persaingan usaha tidak sehat;

3) Membahayakan pertahanan dan keamanan negara. Secara spesifik disebut: a, Informasi tentang strategi, intelijen, operasi, taktik, dan teknik yang berkaitan dengan penyelenggaraan sistem pertahanan dan keamanan negara, meliputi perencanaan, pelaksanaan, dan pengakhiran atau evaluasi dalam kaitan dengan ancaman dalam negeri dan luar negeri, $b$, Dokumen yang memuat tentang strategi, intelijen, operasi, teknik, dan taktik yang berkaitan dengan penyelenggaraan sistem pertahanan dan keamanan negara yang meliputi tahap perencanaan, pelaksanaan, pengakhiran atau evaluasi, c, Jumlah, komposisi, disposisi, atau alokasi kekuatan dan kemampuan dalam penyelenggaraan sistem perthanan dan keamanan (hankam) serta rencana pengembangannya, $d$, 
Gambar dan data tentang situasi dan keadaan pangkalan dan/atau instalasi militer, e, Data perkiraan kemampuan militer dan pertahanan negara lain terbatas pada segala tindakan dan/atau indikasi negara tersebut yang dapat membahayakan kedaulatan Negara Kesatuan Republik Indonesia dan/atau terkait kerja sama militer dengan negara lain yang disepakati dalam perjanjian tersebut sebagai rahasia, f, Sistem persandian negara dan $g$, Sistem intelijen negara;

4) Mengungkap kekayaan alam Indonesia;

5) Merugikan ketahanan ekonomi nasional. Secara spesifik disebut: a, Rencana awal pembelian dan penjualan mata uang nasional atau asing, saham, dan aset vital milik negara, $b$, Rencana awal perubahan nilai tukar, suku bunga, model operasi institusi keuangan, c, Rencana awal perubahan suku bunga bank, pinjaman pemerintah, perubahan pajak, tarif, atau pendapatan negara/daerah lainnya, d, Rencana awal penjualan atau pembelian tanah atau properti, e, Rencana awal investasi asing, f, Proses dan hasil pengawasan perbankan, asuransi, atau lembaga keuangan lainnya, g, Hal-hal yang berkaitan dengan proses pencetakan uang;

6) Merugikan kepentingan hubungan luar negeri. Berupa informasi spesifik mengenai: a, Posisi, daya tawar, dan strategi yang akan dan telah diambil oleh negara dalam hubungan dengan negosiasi, b, internasional, c, Korespondensi diplomatik antarnegara. Sistem komunikasi dan persandian yang dipergunakan dalam menjalankan hubungan internasional, d, Perlindungan dan pengamanan infrastruktur strategis Indonesia di luar negeri;

7) Mengungkap isi akta autentik yang bersifat pribadi, kemauan terakhir, atau wasiat seseorang (Hal ini terkait dengan UndangUndang Nomor 2 Tahun 2014 tentang Perubahan Atas Undang-Undang Nomor 30 tahun 2004 tentang Jabatan Notaris);
8) Mengungkap rahasia pribadi, yaitu: a) Riwayat dan kondisi anggota keluarga; b) Riwayat, kondisi dan perawatan, pengobatan kesehatan fisik, dan psikis seseorang, c) Kondisi keuangan, aset pendapatan, dan rekening bank seseorang, d) Hasil-hasil evaluasi sehubungan dengan kapabilitas, intelektualitas, dan rekomendasi kemampuan seseorang, e) Catatan yang menyangkut pribadi seseorang yang berkaitan dengan kegiatan satuan pendidikan formal dan satuan pendidikan nonformal;

9) Memo dan surat-surat antar-badan publik dan intra-badan publik yang menurut sifatnya dirahasiakan kecuali atas putusan Komisi Informasi atau pengadilan; dan

10) Informasi yang tidak boleh diungkapkan berdasarkan undang-undang. Misalnya: Undang-Undang Nomor 30 Tahun 2000 tentang Rahasia Dagang. Secara leksikal, "menghambat" berarti membuat sesuatu menjadi lambat atau tidak lancar; menahan. Bisa juga diartikan upaya menghalangi.

\subsection{Membentuk Kinerja ASN Yang Berkarakter Dan Proporsional Pasca Berlakunya Undang-Undang Keterbukaan Informasi Publik}

Salah satu elemen penting dalam mewujudkan penyelenggaraan negara yang terbuka adalah hak publik untuk memperoleh informasi sesuai dengan peraturan perundang-undangan. Hak atas Informasi menjadi sangat penting karena makin terbuka penyelenggaraan negara untuk diawasi publik, penyelenggaraan negara tersebut makin dapat dipertanggungjawabkan. Hak setiap orang untuk memperoleh informasi juga relevan untuk meningkatkan kualitas partisipasi masyarakat dalam proses pengambilan keputusan publik. ASN sebagai bagian dari pemerintahan maka wajib untuk mewujudkan keterbukaan informasi publik, untuk mewujudkan pemerintahan yang baik bagi masyarakat dan negara.

Thomas R. Dye (1978: 3) mengemukakan bahwa Public policy is whatever government choose to do or not to do (kebijakan publik adalah apa saja yang dipilih oleh pemerintah untuk 
dilakukan atau untuk tidak dilakukan). Meskipun memberikan pengertian kebijakan publik hanya memandang dari satu sudut saja (yakni pemerintah), namun apa yang diungkap oleh Thomas Dye telah memberikan nuansa terhadap pengertian kebijakan publik. kebijakan bukan hanya keinginan pemerintah, akan tetapi masyarakat pun juga memiliki tuntutan-tuntutan (keinginan), sebab pada prinsipnya kebijakan publik itu mencakup apa yang dilakukan, mengapa mereka melakukannya, dan bagaimana akibatnya. ${ }^{31}$

Menurut Edwards III (1980) terdapat empat faktor yang merupakan syarat utama keberhasilan proses implementasi, keempat faktor ini berfungsi secara berkesinambungan dan terkait satu sama lain untuk membantu dan menghambat implementasi kebijakan, sehingga pendekatan yang ideal adalah dengan cara merefleksikan kompleksitas ini dengan membahas semua faktor tersebut sekaligus. Empat faktor tersebut antara lain: ${ }^{32}$

a) Komunikasi. Dalam menghasilkan implementasi kebijakan yang efektif, pihak-pihak yang pelaksana harus mengetahui apa yang akan mereka lakukan, sedangkan bagi pihak yang berwenang memberikan arahan harus dapat mengarahkan secara informasi secara jelas, akurat, dan konsisten sehingga tidak menimbulkan ambiguitas implementasi. Komunikasi dilakukan agar perintah dan arahan kebijakan dapat tersampaikan dengan baik. Komunikasi biasanya dilaksanakan oleh atasan yang telah memahami sebuah kebijakan kepada bawahan atau implementer yang akan melaksanakan kebijakan tersebut;

b) Sumber daya.Sumber daya meliputi empat komponen yaitu staf yang cukup (jumlah dan mutu), informasi yang dibutuhkan guna pengambilan keputusan, kewenangan yang cukup guna melaksanakan tugas atau tanggung jawab,

31 Adinda Permatasari Rahadian. (2010) Analisis Implementasi Kebijakan Tentang Keterbukaan Informasi Publik Studi Kasus Pada Kementerian Pertanian. Jakarta: Biro Umum dan Humas Kementerian Pertanian. p. 7. dan fasilitas yang dibutuhkan dalam pelaksanaan. Sumber daya yang tidak dapat memenuhi kebutuhan akan berdampak pada hukum yang sulit ditegakkan, pelayanan yang tidak akan tersedia, serta kebijakan yang ada sulit untuk dikembangkan. Dalam menjelaskan sumber-sumber kebijakan yang berpengaruh dalam implementasi dilakukan analisis terhadap indikatorindikator yang mendukung sumbersumber antara lain Staf, Informasi, Kewenangan, dan Fasilitas. Sebagai kebijakan baru yang memiliki pengaruh yang besar untuk merubah kebiasaan ketertutupan birokrasi, amanat dan aturan dalam UU KIP masih harus dipahami lebih lanjut oleh para pelaksana kebijakan tersebut. Dalam hal ini dibutuhkan adanya sharing information dari pihak yang lebih memahami UU KIP tersebut;

c) Disposisi atau sikap pelaksana merupakan komitmen pelaksana terhadap program. Karena seringkali diskresi yang dimiliki pelaksana menjadi kendala dalam implementasi kebijakan yang efektif. Dalam melaksanakan sebuah kebijakan, sikap pelaksana sangat menentukan apakah sebuah kebijakan dijalankan sesuai dengan tujuan awal ataukan kebijakan tersebut dijalankan tidak sesuai arahan. Ketika sebuah kebijakan tidak dijalankan sesuai dengan arahan dalam hal ini terdapat suatu bentuk penolakan dari pelaksana untuk menjalankan kebijakan; dan

d) Struktur birokrasi didasarkan pada standard operating procedures (SOP) yang mengatur tata aliran kerja. Organisasi yang memiliki prosedur perancanaan dan pengawasan program yang lebih fleksibel, akan lebih mudah beradaptasi dengan tanggung jawabnya yang baru, dibandingkan dengan organisasi yang

32 Asri Pancari \& Kusnar Budi. (2014). “Analisis Implementasi Undang-Undang Keterbukaan Informasi Publik Oleh Dinas Pendidikan DKI Jakarta", Jurnal Ilmu Administrasi. 2 (1). p. 12. 
tidak memiliki karakteristik tersebut. Struktur birokrasi didilihat dari dua karakteristik utamanya yaitu SOP yang dibutuhkan internal untuk menyeragamkan dalam bekerja serta fragmentasi yaitu tekanan-tekanan dari eksternal yang dapat mempengaruhi organisasi birokrasi-birokrasi pemerintah. Dalam menjalankan Keterbukaan Informasi Publik, pembentukan SOP merupakan salah satu aspek untuk melihat kepatuhan Badan Publik terhadap UU KIP.

Keterbukaan ini juga secara tegas-tegas dinyatakan di dalam UU ASN di dalam BAB II, megenai Asas, Prinsip, Nilai Dasar, Serta Kode Etik Dan Kode Perilaku, di dalam Pasal 2 huruf (i) menyatakan penyelenggaraan kebijakan dan Manajemen ASN berdasarkan pada asas keterbukaan. Sedangkan di dalam Penjelasan UU ASN dinyatakan bahwa yang dimaksud dengan "asas keterbukaan" adalah bahwa dalam penyelenggaraan Manajemen ASN bersifat terbuka untuk publik.

Ada berbagai cara di dalam membentuk ASN yang berkarakter dan proporsional terdapat yaitu:

1. Jika dilihat dalam rancangan UndangUndang ASN yang menyatakan untuk membentuk Komisi Aparatur Sipil Negara (KASN). Dimana KASN terdiri dari 3-5 anggota adalah lembaga Negara yang bertugas merumuskan regulasi tentang profesi ASN dan mengawasi pelaksanaan regulasi tersebut oleh instansi Pemerintah, pemerintah derah, dan perwakilan Repubik Indonesia di Luar Negeri. Selain itu, KASN berfungsi menetapkan peraturan mengenai profesi ASN dan mengawasi pelaksanaan regulasi tersebut oleh Instansi dan Perwakilan. KASN berkedudukan di ibukota negara dan dalam menjalankan tugas dan wewenangnya berasaskan:33 1) profesionalitas; 2) keadilan; 3) nondiskriminasi; 4) tidak memihak; 5)

33 Naskah Akademik Rancangan Undang-Undang Tentang Aparatur Sipil Negara, p. 48. keterbukaan; 6) akuntabilitas; dan 7) kerahasiaan. Mengingat salah satu kualitas pelayanan publik adalah keterbukaan informasi, maka KASN akan mengawasi bagaimana kinerja ASN dalam menyediakan informasi kepada publik.

2. Memanfaatkan teknologi informasi komunikasi (TIK), yang menyediakan data-data keterbukaan informasi publik kepada masyarakat melalui website, sehingga masyarakat bisa mengakses melalui media internet. Lebih lanjut $C$. Suprapti ${ }^{34}$ menyatakan untuk mewujudkan good governance sudah saatnya pemerintah dalam hal ini Badan Publik pemerintah memanfaatkan perkembangan TIK dengan membangun sebuah sistem informasi yang berbasis TIK. Untuk mengatasi keterbatasan sumber daya manusia di bidang TIK, pemerintah hendaknya mulai memikirkan untuk merekrut sumber daya manusia di bidang TIK, agar kendala-kendala dalam mengelola informasi berbasis TIK bisa teratasi. Perkembangan TIK yang begitu pesat dewasa ini, telah melahirkan sebuah media baru. Media tersebut menjadi tempat bagi Badan Publik pemerintah untuk meningkatkan pelayanan kepada publik atau masyarakat, khususnya pelayanan informasi. Pengelolaan informasi berbasis TIK menjadi salah satu upaya bagi Badan Publik untuk memberikan layanan informasi kepada publik atau masyarakat, karena hal tersebut akan memudahkan publik atau masyarakat mengakses informasi secara cepat dan murah, namun dalam kenyataannya belum semua Badan Publik mengelola informasi berbasis TIK, karena terkendala beberapa hal terutama keterbatasan infrastruktur dan sumber daya manusia di bidang TIK;

3. Pelaksanaan UU KIP, perlu terus disosialisasikan baik kepada Badan Publik maupun masyarakat selaku pemohon informasi. Badan Publik wajib menerapkan

34 C. Suprapti Dwi Takariani, Op.cit, p. 38. 
prinsip keterbukaan informasi publik, dengan memberikan informasi publik secara cepat, sederhana dan biaya murah. Salah satu indikator pelayanan informasi publik yang cepat, sederhana dan biaya murah itu adalah dengan membentuk PPID (Pejabat Pengelola Informasi dan Dokumentasi). Melalui PPID inilah akses informasi diharapkan bisa disampaikan kepada pemohon, sehingga transparansi dan pelayanan informasi yang cepat bisa terlaksana. ${ }^{35}$ Dengan cara mensosialisasikan diri sehingga bisa mengingatkan bahwa harus ada keterbukaan dalam mendukung kinerja ASN yang berkarakter dan proporsional;

4. Badan publik diberikan ruang untuk membentuk, membangun, dan mengembangkan kelembagaan PPID sesuai dengan karakteristik lembaga masing-masing badan publik. Berdasarkan pemikiran tersebut, terdapat dua pilihan bagi badan publik di tingkat daerah, yaitu: a) membentuk organisasi baru sebagai PPID; atau b) melekatkan fungsi PPID dalam struktur organisasi yang telah ada yang relevan dengan tugas pengelolaan dan pelayanan informasi. ${ }^{36}$ Tugas dan wewenang "Atasan PPID" menurut UU KIP hanya memberikan tanggapan atas keberatan yang diajukan oleh Pemohon Informasi dalam bentuk keputusan tertulis. Putusan "Atasan PPID" dapat: Merima seluruh atau sebagian keberatan yang diajukan Pemohon Informasi. Jika ini terjadi, maka dalam Putusan Atasan PPID berisi perintah kepada PPID untuk memberikan sebagian atau seluruh Informasi tersebut. Menolak keberatan yang diajukan Pemohon Informasi. ${ }^{37}$ Jika ini terjadi, maka dalam Putusan Atasan PPID dapat menguatkan Putusan PPID yang telah menolak permohonan atau

35 I Gede Agus Astapa. (2015) "Keterbukaan Informasi Mencegah Budaya KKN". Jurnal Komunikasi FIKOM Universitas Dwijendra, 5 (2). p. 15.

36 Dessy Eko Prayitno, et-al. (2013) Melaksanakan Undang-Undang Tentang Keterbukaan Informasi Publik, Jakarta: International Center for menambah alasan-alasan baru penolakan permohonan;

5. Pemerintah harus dapat mengoptimalkan sosialisasi dan mendorong peran serta masyarakat untuk dapat menjalankan keterbukaan informasi, sebagai amanat UU $\mathrm{KIP}, 38$ sehingga permohonan informasi publik yang diajukan benar-benar didasarkan pada adanya kepentingan masyarakat yang sesuai dengan kebutuhan.

\section{Kesimpulan dan Saran}

\subsection{Kesimpulan}

Implikasi penerapan UU KIP terhadap masyarakat atau publik adalah terbukanya akses bagi publik untuk mendapatkan informasi yang berkaitan dengan kepentingan publik, terbukanya akses bagi publik untuk berpartisipasi aktif dalam proses pembuatan kebijakan publik, termasuk didalamnya akses untuk pengambilan keputusan dan mengetahui alasan pengambilan keputusan yang berkaitan dengan kepentingan publik. UU KIP memilah informasi publik dalam dua kategori: Pertama, Informasi yang wajib disediakan dan diumumkan, terdiri atas: 1) Informasi yang Wajib Disediakan dan Diumumkan Secara Berkala (minimal $1 \times 6$ bulan) dan2) Informasi yang Wajib Diumumkan Serta-Merta (mudah dijangkau dan mudah dipahami). Kemudian implikasi yang dipandang sangat penting adalah dengan adanya penerapan UU KIP ini daya kritis masyarakat atau publik terhadap kinerja penyelenggaraan pemerintahan terutama pelayanan publik semakin meningkat dan diperkirakan tingkat penilaian atau pengaduan masyarakat atau publik terhadap kualitas layanan publik juga semakin meningkat.

Environmental Law. p. 20.

37 Fauzi Syam, Op.cit, p. 53.

38 Asri Pancari dan Kusnar Budi (2014), “Analisis Implementasi Undnag-Undang Keterbukaan Informasi Publik Oleh Dinas Pendidikan DKI Jakarta". Jurnal Ilmu Administrasi. 3 (1). p. 14. 
Membentuk ASN yang berkarakter dan proporsional terdapat yaitu ada berbagai cara yaitu: 1) Komisi Aparatur Sipil Negara (KASN); 2) Memanfaatkan teknologi informasi komunikasi (TIK), yang menyediakan datadata keterbukaan informasi publik kepada masyarakat melalui website; 3) Pelaksanaan UU KIP; 4) perlu terus disosialisasikan baik kepada Badan Publik maupun masyarakat; 5) Badan publik diberikan ruang untuk membentuk, membangun, dan mengembangkan kelembagaan PPID sesuai dengan karakteristik lembaga masing-masing badan publik; 6) Pemerintah harus dapat mengoptimalkan sosialisasi dan mendorong peran serta masyarakat untuk dapat menjalankan keterbukaan informasi, sebagai amanat UU KIP. Dengan cara-cara tersebut diharapkan akan mewujudkan ASN yang berkarakter dan proporsional yang juga amandat dari UU KIP.

\subsection{Saran}

1. ASN diharapkan dapat bekerja dengan lebih baik terutama dalam menyediakan informasi bagi masyarakat, karena melalui keerbukaan informasi, maka masyarakat akan bisa menyampaikan hal-hal yang penting jika terjadi kesalahan di dalam kinerja atau rancangan yang telah dan akan dikerjakan oleh Badan Publik, sehingga mewujudkan kepentingan yang terbaik bagi publik;

2. UU KIP juga sebagai auto kritik bagi pemerintah, dimana pemerintah perlu memperhatikan dan meninjau kembali, jika ada celah atau kelamahan didalam UU KIP yang dapat disalah gunakan oleh banyak pihak, untuk kepentigannya sendiri. Dengan kelemahan ini, pada akhirnya akan membuat Badan Publik ataupun masyarakat tidak percaya terhadap kekuatan hukum UU KIP serta dampak yang lebih buruk adalah meninggalkan pelaksanaan UU KIP karena hanya dapat menghasilkan praktik-praktik negatif;

3. Harus ada kerjasama yang baik antara PPID, ASN dan Mayarakat dalam melaksanakan UU KIP, sehingga ASN dapat bekerja secara terbuka agar mewujudkan ASN yang berkarakter dan proporisonal, sebagai modal untuk mewujudkan negara Indonesia yang terbuka dan sejahtera.

\section{Daftar Pustaka}

Buku

Adinda Permatasari Rahadian. (2010). Analisis Implementasi Kebijakan Tentang Keterbukaan Informasi Publik Studi Kasus Pada Kementerian Pertanian. Jakarta: Biro Umum dan Humas Kementerian Pertanian.

Dessy Eko Prayitno. et-al. (2013) Melaksanakan Undang-Undang Tentang Keterbukaan Informasi Publik. Jakarta: International Center for Environmental Law.

Dewan Perwakilan Rakyat. (2014). Naskah Akademik Rancangan Undang-Undang Tentang Aparatur Sipil Negara. Jakarta: Sekretariat Jenderal Dewan Perwakilan Rakyat.

Dhoho A. Sastro (et-al). (2010). Mengenal Undang-Undang Keterbukaan Informasi Publik. Jakarta: Lembaga Bantuan Hukum Masyarakat.

Henri Subagiyo. (2010). Anotasi Undang-Undang Nomor 14 tahun 2008 tentang Keterbukaan Informasi Publik. Jakarta: Komisi Informasi Republik Indonesia.

Johnny Ibrahim. (2006). Teori dan Metodologi Penelitian Hukum Normatif. Malang: Bayumedia Publishing.

Koalisi Untuk Kebebasan Informasi. (2008) Kebebasan Informasi Di Beberapa Negara. Jakarta: Lembaga Studi Pers dan Pembangunan.

Marnasse Malo dan Sri Trisnongtias. (1997), Metode Penelitian Masyarakat. Jakarta: Pusat Antara Universitas Ilmu-Ilmu Sosial Unversitas Indonesia.

Naskah Akademik Rancangan UndangUndang Tentang Aparatur Sipil Negara.

Penjelasan Pengusul Usul Rancangan UndangUndang Usul Inisiatif Tentang Kebebasan Memperoleh Informasi Publik.

Peter Mahmud Marzuki. (2005). Penelitian Hukum. Jakarta: Kencana Prenada Media Grup. 
Pratikno, et-al. (2012). Kajian Implementasi Keterbukaan Informasi Dalam Pemerintahan Lokal Pasca Undang-Undang Nomor 14 Tahun 2008. Jakarta: Yayasan Tifa.

Risalah Perundang-Undangan Tentang Keterbukaan Informasi Publik.

Soerjono Soekanto. (2008). Pengantar Penelitian Hukum. Jakarta: Penerbit Universitas Indonesia.

\section{Jurnal}

Asri Pancari dan Kusnar Budi. (2014). “Analisis Implementasi Undnag-Undang Keterbukaan Informasi Publik Oleh Dinas Pendidikan DKI Jakarta". Jurnal Ilmu Administrasi. 1 (1).

C. Suprapti Dwi Takariani. (2014). "Pengelolaan Informasi Oleh Badan Publik Pemerintah Paska Reformasi Birokrasi". Jurnal Observasi. 12 (1).

Endang Retnowati. (2012). "Keterbukaan Informasi Publik Dan Good Governance (Antara Das Sein Dan Das Sollen)". Jurnal Perspektif. 17 (1).
Fauzi Syam. (2015). "Hak Atas Informasi Dan Legal Standing Para Pihak Dalam Sengketa Informasi Di Komisi Informasi". Jurnal Inovatif. 8 (1).

I Gede Agus Astapa. (2015). "Keterbukaan Informasi Mencegah Budaya KKN", Jurnal Komunikasi FIKOM Universitas Dwijendra. 5 (1).

Khairunnisa Kamaliah. (2015). "Implementasi Undang-Undang Nomor 14 Tahun 2008 Tentang Keterbukaan Informasi Publik Di Badan Perencanaan Pembangunan Daerah Kota Samarinda". Jurnal Ilmu Pemerintahan. 3 (2).

Nunuk Febrianginsih. (2012). "Keterbukaan Informasi Publik Dalam Pemerintahan Terbuka Menuju Tata Pemerintahan Yang Baik". Jurnal Rechtvinding. 1 (1).

Ridwan Mansyur. (2015). "Keterbukaan Informasi Di Peradilan Dalam Rangka Implementasi Integritas Dan Kepastian Hukum". Jurnal Hukum dan Peradilan. 4 (1). 